\title{
SUBSTANTIATION AND DEVELOPMENT OF NATURAL COLD ACCUMULATOR FOR MILKING AREAS OF REMOTE SUMMER FARM CAMPS
}

\author{
Basil Kvashennikov, Andrey Kozlovtsev, Vladimir Shakhov, Eugene Kochkin \\ Orenburg State Agrarian University, Russia \\ vasiliy056@mail.ru, ap_kozlovcev@mail.ru, shahov-v@yandex.ru, zhekakochkin@gmail.com
}

\begin{abstract}
The dairy industry is undergoing changes due to ever-increasing technologies and introduction of technological advances, which have many advantages. However, each new technology causes some difficulties. For example, summer camps are widely used for keeping cows in the summertime, which are 3 to $10 \mathrm{~km}$ away from the main farm. The main, unresolved problem in such camps, which is ubiquitous, is cooling of fresh milk. On the main farm, as a rule, cooling is carried out by machines. But to use refrigeration equipment in summer camps is not economically feasible. Milk, most often, is not cooled, but transported to a dairy processing plant. Taking into account the duration of milking and subsequent transportation, the duration of the stay of fresh milk without cooling is several times higher than the permissible values. In reducing the grade of milk in such cases, manufacturers suffer large financial losses. Milk can be cooled in such cases by the natural cold accumulated in winter in the form of water ice. Such accumulation can be carried out using a thermosiphon system. However, in such a system, freezing of ice will inevitably lead to destruction of the ice accumulator. We propose a relatively simple and low-cost method of protecting the pool walls in a remote camp while freezing ice with a thermosiphon system. This will allow to completely eliminate the destruction. Also, this method is economically feasible due to reduction of the transportation costs and cooling of the milk itself with the help of refrigeration units with high power consumption.
\end{abstract}

Keywords: natural cold, thermosyphon, ice accumulator, milk cooling, safety unit.

\section{Introduction}

Remote summer farm camps are widely used for keeping cows in central Russia in summertime. The remotness of such camps from the main farm ranges from 3 to $10 \mathrm{~km}$. The duration of such a period is 4 to 5 months a year.

In this case, the main, unresolved issue is cooling of freshly drawn milk. On the main farm cooling is carried out by machines, as a rule. But it is not economically feasible to use refrigeration equipment in summer farm camps, for that reason milk is not cooled there. After milking fresh milk is pumped into a milk tanker and delivered to the main farm for cooling or to a milk processing enterprise [1;2].

Taking into account the duration of milking and the subsequent transportation of milk without cooling, the bacterial count increases significantly. In such cases, following milk downgrading manufacturers suffer large financial losses.

Milk can be cooled to $4-5^{\circ} \mathrm{C}$ in the milking areas of remote summer farm camps by natural cold accumulated in winter in the form of water ice. Such accumulation can be carried out using a thermosyphon system [3;4].

For this purpose, it is necessary to build a sunken pool with insulated walls next to the milking platform. The working volume of the basin $\mathrm{V}_{\sigma}$ is determined on the basis of the average daily milk yield for the entire period of housing, the duration of the lager period and the number of cows:

$$
V_{\sigma}=\frac{m y_{c y m} \cdot N_{c y m} \cdot C\left(t_{\text {нач }}-t_{\text {кон }}\right) \cdot \eta}{q \rho_{\pi}},
$$

where $m, y_{c y m}, N_{c y m}-$ accordingly, number of cows, heads; daily milk yield, $\mathrm{kg} \cdot\left(\right.$ heads $\cdot$ day) ${ }^{-1}$; duration of the lager period, days;

$C, t_{\text {нач }}, t_{\text {кон }}, \eta$ - respectively, heat capacity of milk, $\mathrm{kJ} \cdot(\mathrm{kg} \cdot \text { degrees })^{-1}$; initial and final temperature of milk, ${ }^{\circ} \mathrm{C}$; ice loss rate due to unauthorized heat leakage, equal to 1.2-1.4; $Q, \rho_{l}-$ respectively, specific heat of ice melting, $\mathrm{kJ} \cdot \mathrm{kg}^{-1}$ and ice density, $\mathrm{kg} \cdot \mathrm{m}^{-3}$.

The use of thermosyphons for ice accumulation in the sunken pool is predetermined by their positive properties. During operation they do not consume energy, do not require maintenance for a long time - for about 20-30 years, they operate around the clock during the frosty period, do not 
transfer heat in the opposite direction (from ambient air to the deep layers of the ice pool) during the period of positive ambient air temperatures.

\section{Materials and methods}

Thermosyphons, produced today by Russian manufacturers, are charged with ammonia, carbon dioxide, less often with freon. Ammonium carbonic thermosyphons begin to freeze ice on the lateral surface of the evaporator only when the temperature difference between the condenser of the thermosyphon and the evaporator is $12{ }^{\circ} \mathrm{C}$, i.e. on the evaporator of thermosyphon the negative temperature will be only when the condenser is set at minus $12^{\circ} \mathrm{C}$ and below.

In the autumn-winter period the weather conditions most often develop in such a way that the air temperature does not exceed the zero mark $\left(0\right.$ to $\left.-12{ }^{\circ} \mathrm{C}\right)$ for 30 days or more. During this period, the surface layer of water freezes. Over time, the thickness of the ice layer in the pool increases due to the advance of the freezing front, by the beginning of functioning of thermosyphons the thickness of the surface ice layer will be $25-35 \mathrm{~cm}$. The strength properties of this layer are comparable to the properties of reinforced concrete walls of the pool.

It is well known that the volume of ice exceeds the volume of water from which this ice is formed by $9.055 \%$. For example, if a basin with a water volume of $100 \mathrm{~m}^{3}$ is completely frozen, the ice volume is $109.055 \mathrm{~m}^{3}$. The formation of "extra" 9055 liters in the closed subglacial space of the basin causes enormous pressure of hundreds of MPa.

In such cases the events will occur according to one of the following options:

- strength characteristics of the ice layer will exceed the similar characteristics of the walls. There will be random and numerous cracks on the walls, through which water can completely escape from the pool.

- strength characteristics of the walls are higher than those of the ice layer. The ice will swell and crack. Ice drifts can damage thermosyphon vaporizers causing the loss of their tightness. The refrigerant will evaporate and the thermosyphon will not work.

Cracking of the ice layer is very often observed on natural water bodies with stagnant water, despite the fact that the bottom and side walls of water bodies are covered with muddy deposits.

Scientists have proposed several technical solutions to prevent the pool walls from destruction.

In the research [1], they propose to place a compensator in a frozen container, which is a corrugated hollow cylinder, the inner surface of which is connected to the atmosphere through a special tube. As the water pressure increases, the cylinder shrinks, pushing air into the atmosphere, thereby compensating for the increase in volume during ice freezing. For economic reasons this device is not acceptable for a summer remote camp.

In works [3], they offer to use a system that allows water to increase from the under-ice space to the over-ice, when the pressure in the under-ice space increases. Measuring the volume of water flowing, it is relatively easy to calculate the mass of frozen ice $M_{n}[2]$.

$$
M_{l}=k \Delta V,
$$

where $k$-anomaly coefficient of water, equal to $11044 \mathrm{~kg} \cdot \mathrm{m}^{-3}$;

$\Delta V$ - volume of water flowing from the under-ice space into the over-ice space, $\mathrm{m}^{3}$.

Despite all the seeming simplicity of this system, its use in the pool of a remote summer camp is impossible for two reasons:

- summer farm camp does not function in the winter time, the power line is de-energized;

- system can function only if there is a heated room, which cannot be there.

\section{Results and discussion}

We propose a relatively simple and low-cost method of protecting the walls of the pool, when the ice is frozen with a thermosyphon system (Fig. 1).

Floating safety unit (FSU) is an aluminum hollow closed cone, at the top of which the load-ballast is placed (for example, lead shot). The entire surface of the cone is coated with an anti-adhesive 
coating OS-56-11c or OS-56-22, which reduces the adhesive strength of the ice-adhesive coating contact by almost 5 times [5].

The principle of operation of the FSU in a pool equipped with a thermosyphon system is as follows (Fig. 2).

Before the beginning of the frosty period, the FSU is lowered into the water in the center of the pool in "free swimming". When an ice crust appears on the surface of the FSU pool, this crust is fixed in some place of the pool surface. As the crust thickens in the subglacial space of the basin, due to the reasons described earlier, the pressure increases.

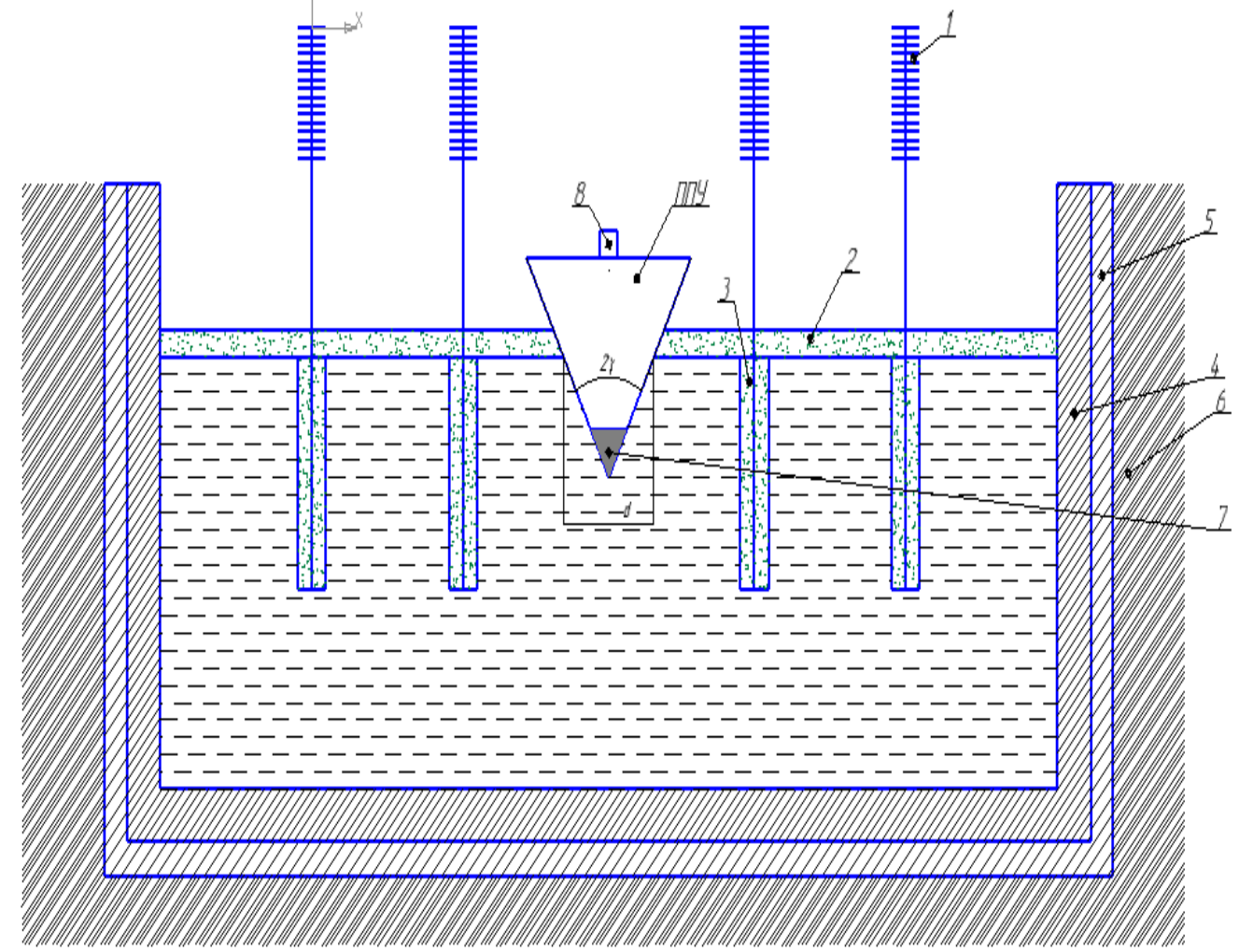

Fig. 1. Scheme of basin for freezing ice with thermosyphon system with safety unit against pressure increase in under-ice space: 1 - thermosyphon capacitor; 2 - surface layer of ice; 3 - ice frosting on thermosyphon vaporizers; 4 - reinforced concrete wall of the pool; 5 - thermal insulation of the pool walls; 6 - ground; 7 - load ballast; 8 - pipe for loading ballast weight; FSU - floating safety unit

According to the Pascal's law the pressure acts equally on all structural elements of the pool walls, surface ice layer, thermosyphons, FSU, etc. But the strength of the reinforced concrete walls and the strength of the ice layer significantly exceed the contact strength of the side surface of the FSU with ice, as it has an anti-adhesive coating.
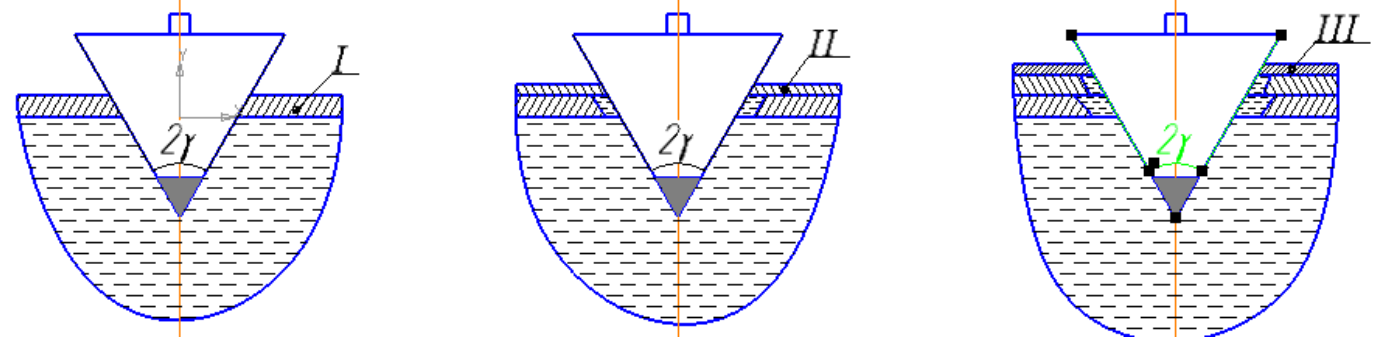

Fig. 2. Scheme of floating safety unit operation when freezing ice in pool I, II, III - ice layers

FSU under the action of excess pressure separates from the ice layer and floats upwards, forming an annular gap. Water from the under-ice space flows through the annular gap to the surface of the ice layer, forming a new frozen layer II (Fig. 2). The pressure in the ice space drops. FSU freezes in the II 
layer. After a certain time, the process repeats, FSU freezes into the III layer, etc. The process is repeated cyclically.

Due to the fact that the mass of ice frozen on the evaporators of thermosyphons considerably exceeds the mass of ice in the layers II, III, IV, etc. FSU actuation always occurs with an insignificant thickness of the layers, in which FSU is frozen. The reliability of operation depends on the properties of the anti-adhesive coating FSU and design features.

N.S. Kornoukhova, R.V. Golshtein, V.P. Epifanov et al. studied the adhesion strength of ice frozen on the surface of elements of technical devices. (Fig. 3) [5- 7].
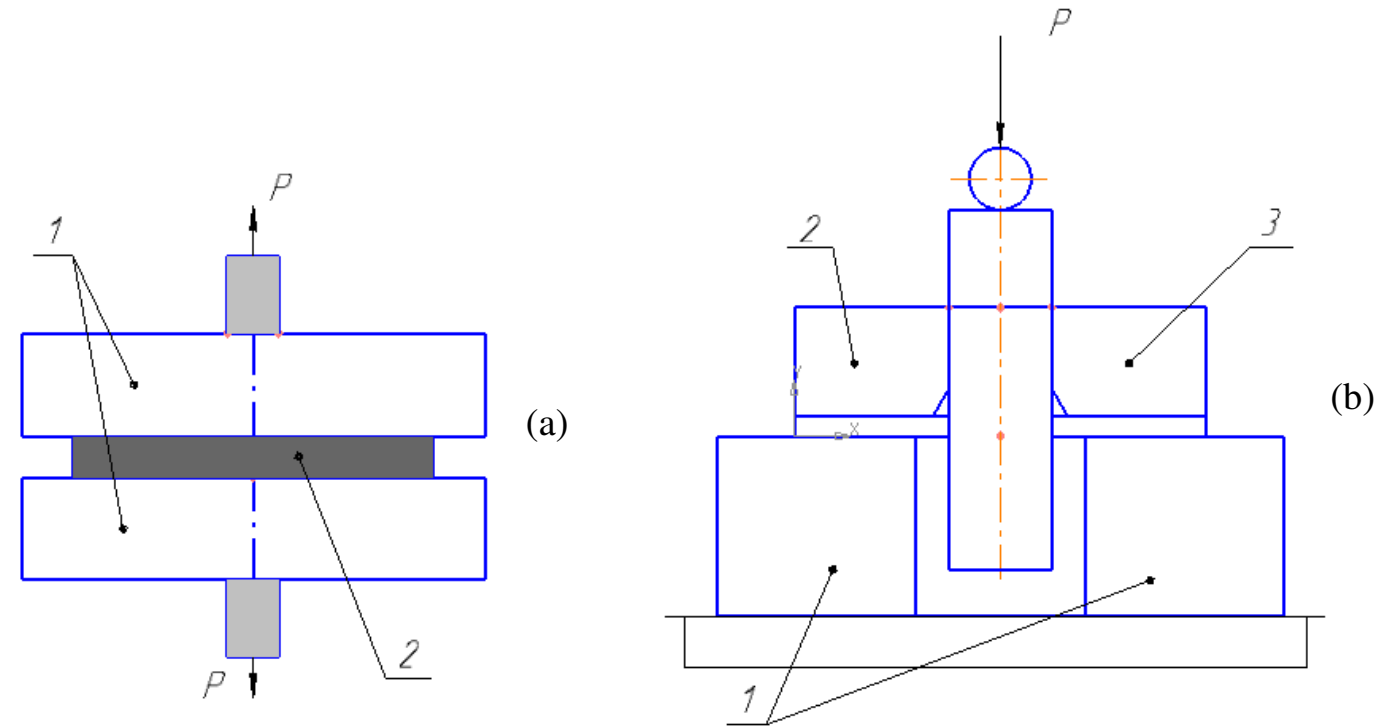

Fig. 3. Scheme of experiment to the gap (a) and on axial shift (b): 1 - bearing; 2 - ice; 3 - rod

According to R.V. Golshtein and V.P. Epifanova [5], the normal stress of breaking ice from an aluminum surface without coating $\sigma_{n}^{\prime}$ is $(0.48 \pm 0.01) \mathrm{MPa}, \sigma_{n}=(0.108 \pm 0.008) \mathrm{MPa}$. The shear stresses are respectively $\tau_{s}{ }^{\prime}=(0.49 \pm 0.02) \mathrm{MPa}$ and $\tau_{s}=(0.105 \pm 0.02) \mathrm{MPa}$.

These values of $\sigma_{n}$ and $\tau_{s}$ allow us to calculate the design and technological parameters of the floating safety unit.

The method of calculation of structural and technological parameters of FSU.

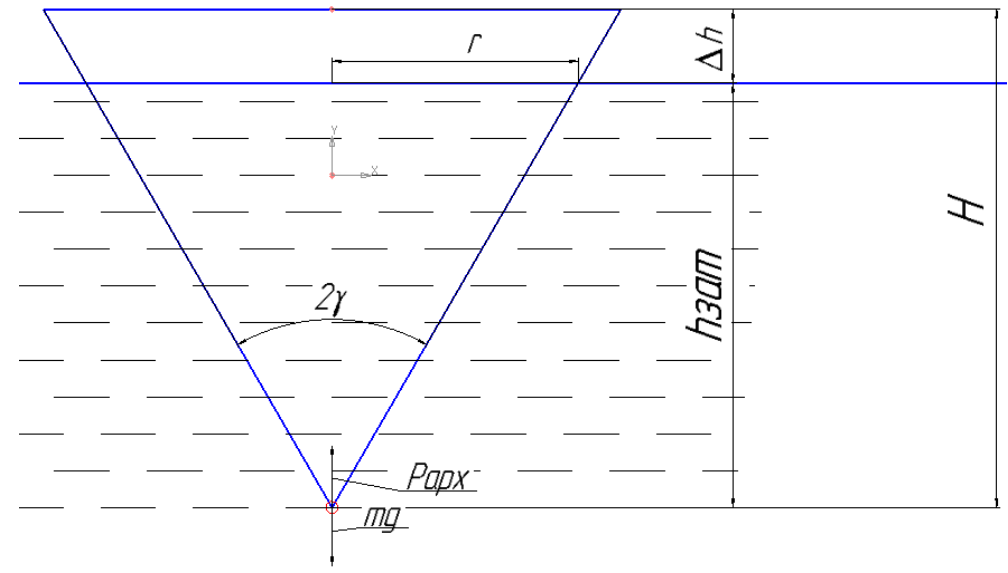

Fig. 4. FSU design diagram

Based on the navigation conditions

$$
P_{a p x}=m g,
$$

where $P_{a p x}-$ Archimedean force;

$m$ - mass of displaced water;

$g-$ acceleration of free fall. 
In this case, the Archimedean force is also equal to the product of the volume of the submerged part $V_{\text {заm }}$, the density of the fluid $\rho_{\mathrm{B}}$ and the acceleration of gravity $g$. Therefore, the equality is true:

$$
V_{\text {заm }} \rho_{8} g=m g
$$

We calculate the volume of the flooded part by the formula:

$$
V_{\text {зат }}=\frac{1}{3} \pi r^{2} h_{\text {зат }},
$$

where $r$-radius of the cylinder circumference on the border with water, $\mathrm{mm}$

$h_{\text {заm }}$ - height of the flooded part of the cylinder, mm.

At the same time, from Figure 4 it follows that

$$
r=h_{\text {заm }} \operatorname{tg} \gamma,
$$

Substituting the value of $V_{3 а m}$ and $r$ into the condition of the floating bodies, we get:

$$
\frac{1}{3} \pi r^{2} h_{\text {зат }} \rho_{6} g=m g,
$$

where $\rho_{s}$ - density of water at $0{ }^{\circ} \mathrm{C}$, equal to $999.8 \mathrm{~kg} \cdot \mathrm{m}^{-3}$.

Substituting the values of $r$ from expression (5) into (6) and having performed some transformations, we get:

$$
h_{\text {зат }}=\sqrt[3]{\frac{3}{\pi \rho_{\theta}} \cdot \frac{m}{\operatorname{tg}^{2} \gamma}}
$$

or, rounding off

$$
h_{\text {зат }}=0.1 \sqrt[3]{\frac{m}{\operatorname{tg}^{2} \gamma}},
$$

The total height $\mathrm{H}$ is selected from the condition $\Delta h \geq 0.1 \mathrm{~m}$.

The pull-off force $R_{o m}$ of the FSU from the ice layer depends on its mass, the formation thickness " $b$ ", angle $\gamma$ and the adhesion stresses $\sigma_{n}$ and $\tau_{s}$. The calculation method is standard and is carried out according to the laws of theoretical mechanics, physics, resistance of materials, heat engineering and hydraulics (Fig. 5).

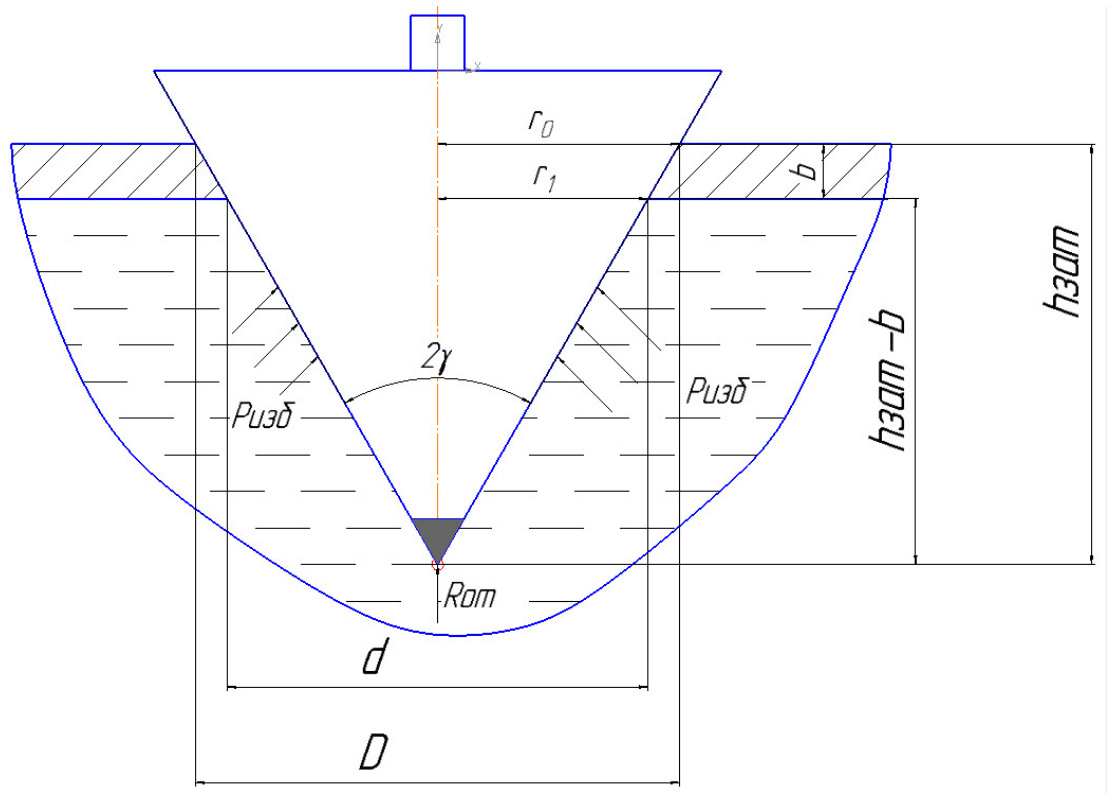

Fig. 5. Calculation of effort of separation of FSU frozen in ice 


\section{Conclusions}

The problem of preserving the milk quality while receiving it is relevant not only for large dairy farms, but also for peasant and private farms. That fact has justified the need to find new solutions to the problem of developing research methodologies for various life cycles of a technical object, which help preserve the quality of milk due to its timely and high-quality cooling, guarantee the stability of the parameters by their control system, and create an effective process of year-round cooling of the products obtained.

The analysis of the studies in milk cooling with the help of natural cold created the prerequisites for substantiating new ice-accumulator water circulation systems that reduce the costs of the cooling process. Such systems and technologies have great advantages over the existing ones and are relevant for modern agriculture in milk cooling.

Theoretical and experimental studies have allowed the development of a safety unit to protect the walls of the ice storage facility from destruction during ice freezing. The relatively simple and lowcost method of protecting the walls of the pool while freezing ice with a thermosiphon system, that we propose, makes it possible to completely eliminate the destruction in the winter season. This ensures accumulation of ice in the frosty period for its further use in the milk cooling system in summer.

\section{References}

[1] Босин И.Н. (Bosin I.N.) Аккумулятор естественного холода. (Akkumulyator estestvennogo kholoda) (Natural cold accumulator). Сельский механизатор, 1997. №4. 32 c. (Rural Mechanic, 1997. No4. 32 p.) (In Russian)

[2] Трухачев В.И., Капустин И.В., Будков В.И., Грицай Д.И. (Trukhachev V.I., Kapustin I.V., Budkov V.I., Gritsai D.I.) Технологическое и техническое обеспечение процессов машинного доения коров, обработки и переработки молока: учебное пособие (Tekhnologicheskoye i tekhnicheskoye obespecheniye protsessov mashinnogo doyeniya korov, obrabotki i pererabotki moloka: uchebnoye posobiye) (Technological and technical support of the processes of machine milking of cows, processing and processing of milk: study guide) 2-е изд., стер. - СПб.: Издательство «Лань», 2013. 304 с. (2nd ed., Sr. - SPb .: Lan" Publishing House, 2013. 304 p.) (In Russian)

[3] Завражнов А.И., Квашенников В.И., Козловцев А.П. и др. (Zavrazhnov A.I., Kvashennikov V.I., Kozlovtsev A.P.) Круглогодовое использование природного холода в условиях молочно-товарных ферм Южного Урала: Рекомендации (Kruglogodovoye ispolzovaniye prirodnogo kholoda $\mathrm{v}$ usloviyakh molochno-tovarnykh ferm Yuzhnogo Urala: Rekomendatsii) (Year-round use of natural cold in the conditions of dairy farms of the Southern Urals: Recommendations). Мичуринск: Изд-во Мичуринского ГАУ, 2016. 61 с. (Michurinsk: Publishing House of Michurinsky State Agrarian University, 2016. 61 p. (In Russian)

[4] Чи C. (Chi S.) Тепловые трубы. Теория и практика (Teplovye truby. Teoriya i praktika) (Heat pipes. Theory and practice). М.: Машиностроение, 1981. 207c. (М .: Mashinostroyeniye, 1981. 207 p.) (In Russian)

[5] Гольштейн P.В., Епифанов В.П. (Holstein R.V., Epifanov V.P.) К измерению адгезии льда к другим материалам. (K izmereniyu adgezii lda $\mathrm{k}$ drugim materialam) (To the measurement of ice adhesion to other materials). Вестник Пермского политехнического университета. Механика. 2011. №2 с. 28. (Bulletin of the Perm Polytechnic University. Mechanics. 2011. No2 28 p.) (In Russian)

[6] Blackburn C., Laforte C., Laforte J.L. Apparatus for measuring the adhesion force of a this ice sheet on a substrate. For presentation at the Ninth International Workshop of Atmospheric Icing of Structures. June 5-8, 2000, p. 1.

[7] Matsumoto K., Kobayashi T. Fundamental study on adhesion of ice to cooling solid surface. International Journal of Refrigeration, Vol. 30, 2007, 851 p. 